MAREK SZKLARCZYK

WOJCIECH WESOLOWSKI

MARCELINA WAJDZIK

ANNA SZLACHTOWSKA

BEATA DOMNICZ

ANNA BURDA

Zakład Genetyki, Hodowli Roślin i Nasiennictwa, Instytut Biologii Roślin i Biotechnologii, Wydział Biotechnologii i Ogrodnictwa, Uniwersytet Rolniczy w Krakowie

Kierownik Tematu: dr hab. Marek Szklarczyk Zakład Genetyki, Hodowli Roślin i Nasiennictwa Instytut Biologii Roślin i Biotechnologii Wydział Biotechnologii i Ogrodnictwa Uniwersytet Rolniczy w Krakowie, Al. 29 Listopada 54, 31-425 Kraków, tel. 12 6625328, e-mail: marek.szklarczyk@urk.edu.pl

Prace zostały wykonane $w$ ramach badan podstawowych na rzecz postęp biologicznego w produkcji roślinnej na podstawie decyzji Ministra Rolnictwa i Rozwoju Wsi nr HOR.hn.802.8.2018, Zadanie 68.

\title{
Analiza czynników genetycznych związanych z przywracaniem płodności roślin buraka ćwikłowego
}

Analysis of genetic factors linked to fertility restoration in table beet

Słowa kluczowe: cytoplazmatyczna męska sterylność, genotypowanie, geny restorerowe, markery molekularne

TEMAT BADAWCZY 1: UZYSKANIE POPULACJI MAPUJĄCYCH TYPU BC1

\section{Cele tematu}

Uzyskanie segregujących populacji do mapowania genów przywracających płodność

\section{Opis wyników}

Badany materiał roślinny stanowiły cztery kwitnące potomstwa wywodzące się $\mathrm{z}$ oryginalnego krzyżowania $4357 \mathrm{~A} \times \mathrm{BS}$. Uprawę prowadzono $\mathrm{w}$ polu $\mathrm{z}$ wysadków uzyskanych $\mathrm{w}$ roku ubiegłym. W czasie kwitnienia roślin wizualnie sprawdzano u nich obecność pyłku. Dla każdej rośliny obserwacje poczyniono minimum dwukrotnie w różnych terminach. Wizualna ocena płodności była weryfikowana poprzez mikroskopową analizę żywotności pyłku. Pomimo, iż wszystkie badane obiekty segregowały na rośliny męskosterylne i męskopłodne, w świetle analizy żywotności pyłku oczekiwane rozszczepienie (1:1) uzyskano tylko dla jednej populacji. 


\section{Wnioski}

- Segregacja fenotypowa tylko jednej z badanych populacji gwarantuje jej użyteczność w analizie genów restorerowych.

\section{TEMAT BADAWCZY 2: GENOTYPOWANIE SEGREGUJĄCYCH POPULACJI MAPUJĄCYCH PRZY ZASTOSOWANIU METODY GBS}

\section{Cele tematu}

Masowa identyfikacja polimorfizmów GBS u roślin różniących się statusem płodności

\section{Opis wyników}

Genotypowaniu poddano dwie populacje z cytoplazmą S i segregacją pod względem fenotypu płodności - 506 oraz 740. Analiza ta była wykonywana $\mathrm{w}$ ramach usługi zleconej firmie Novogene (Chiny). Biblioteki przygotowano z użyciem restryktazy ApeKI. Do sekwencjonowania wysokoprzepustowego wykorzystano platformę firmy Illumina. Zastosowano wariant sekwencjonowania ze sparowanymi końcami i 150 cyklami syntezy (PE150). Długość odczytanych sekwencji wahała się od ok. 300 do ok. $550 \mathrm{Mb}$ dla pojedynczej rośliny. Wskaźniki Q20 i Q30 wyniosły odpowiednio 96 i 91\%, a udział par GC 36-37\%.

\section{Wnioski}

—Dla obydwu badanych populacji uzyskano wystarczającą ilość danych sekwencyjnych. Przy założeniu, iż w genomie buraka sekwencje unikalne stanowią ok. 37\% (210 Mb, Dohm i in., 2014), ich przeciętne pokrycie u pojedynczej rośliny wyniosło ok. 1,4-2,6×.

- Wysoki procent nukleotydów osiągających wskaźniki jakości Q20 i Q30 gwarantuje przydatność otrzymanych danych sekwencyjnych dla analiz bioinformatycznych zmierzających do identyfikacji polimorfizmów pojedynczego nukleotydu (SNP).

\section{TEMAT BADAWCZY 3: ANALIZA BIOINFORMATYCZNA DANYCH SEKWENCYJNYCH}

\section{Cele tematu}

Określenie genomowej lokalizacji zidentyfikowanych markerów GBS i genów restorerowych

\section{Opis wyników}

Analizom poddawano dane sekwencyjne wygenerowane w bieżącym roku dla populacji 506 oraz 740. Przefiltrowane odczyty sekwencyjne były mapowane do sekwencji genomu referencyjnego (AYZS00000000.2) — średni odsetek zmapowanych odczytów wyniósł $96,4 \%$. Średnio $12,3 \%$ genomu referencyjnego było pokryte odczytami sekwencyjnymi (wykazywało pokrycie przynajmniej 1×). W wyniku mapowania odczytów do genomu referencyjnego zidentyfikowano ok. 1,6 mln polimorfizmów sekwencyjnych, które następnie poddawano kilkustopniowej filtracji. Obejmowała ona kolejno selekcję markerów: biallelicznych o wysokiej jakości, z maksymalnie pięcioma nieokreślonymi genotypami, o genotypach odpowiadających charakterowi badanej populacji, o właściwej segregacji oraz oddalonych od siebie o więcej niż $10 \mathrm{~kb}$. 
W rezultacie do mapowania genetycznego wykorzystano ok. 2200 markerów z populacji 506 oraz ok. 1000 markerów z populacji 740. Uzyskano dziewięć grup sprzężeń odpowiadających dziewięciu chromosomom buraka. W przypadku populacji 506 całkowita długość mapy wynosiła $577,2 \mathrm{cM}$ ze średnią długością pojedynczej grupy sprzężeń wynoszącą $64,1 \mathrm{cM}$. Gen restorerowy wraz z 61 markerami GBS zmapował się na chromosomie 3. Najbliższy restorerowi marker GBS zmapował się w odległości $1,7 \mathrm{cM}$. W przypadku populacji 740 całkowita długość mapy wynosiła $526,1 \mathrm{cM}$ ze średnią długością pojedynczej grupy sprzężeń wynoszącą $58,5 \mathrm{cM}$. W utworzonych grupach sprzężeń nie odnotowano obecności restorera.

\section{Wnioski}

- Przy wykorzystaniu technologii GBS otrzymano dane sekwencyjne, które pozwoliły na bardzo wydajną identyfikację markerów i uzyskanie — przynajmniej lokalnie wysoko wysyconych map genetycznych. Dzięki dostępności sekwencji referencyjnej określono chromosomową lokalizację zidentyfikowanych grup sprzężeń.

— Restorer z populacji 506 zmapował się w obrębie chromosomu 3, co wskazuje, iż jest $\operatorname{nim}$ gen $X(R f 1)$ Owena.

\section{TEMAT BADAWCZY 4: KONWERSJA POLIMORFIZMÓW SPRZEŻ̇ONYCH Z GENAMI RESTOREROWYMI W MARKERY TYPU SCAR, CAPS I TETRA-PRIMER ARMS-PCR}

\section{Cele tematu}

Opracowanie markerów PCR do wnioskowania o obecności alleli restorerowych

\section{Opis wyników}

Badany materiał roślinny stanowiły cztery populacje segregujące pod względem fenotypu płodności. Analiza wstępna była prowadzona na 10 roślinach (5 męskopłodnych i 5 męskosterylnych). Markery kosegregujące z fenotypem były użyte do genotypowania całych populacji. Wykorzystywane markery reprezentowały typy CAPS i SCAR. Projektowanie markerów CAPS zautomatyzowano stosując napisany w toku niniejszych prac program VCF2CAPS (Wesołowski). W trzech populacjach testowane markery kosegregowały fenotypem na poziomie do ok. $80 \%$. Były to markery dla genu $X(R f l)$ (rys. 1). W jednej $\mathrm{z}$ analizowanych populacji testowane markery najczęściej nie wykazywały polimorfizmu.

\section{Wnioski}

- Markery CAPS projektowano na bazie zidentyfikowanych uprzednio markerów GBS. Do tego celu wykorzystano autorski program VCF2CAPS (Wesołowski) umożliwiający masową konwersję wykrytych technikami NGS polimorfizmów sekwencyjnych w markery CAPS.

- W trzech populacjach $\mathrm{z}$ fenotypem kosegregowały markery $\mathrm{z}$ chromosomu 3, co potwierdza/wskazuje na występowanie w nich restorera $X / R f 1$. Wartość kosegregacji wynosiła średnio ok. $80 \%$. 
Burak ćwikłowy (Beta vulgaris subsp. vulgaris conditiva)

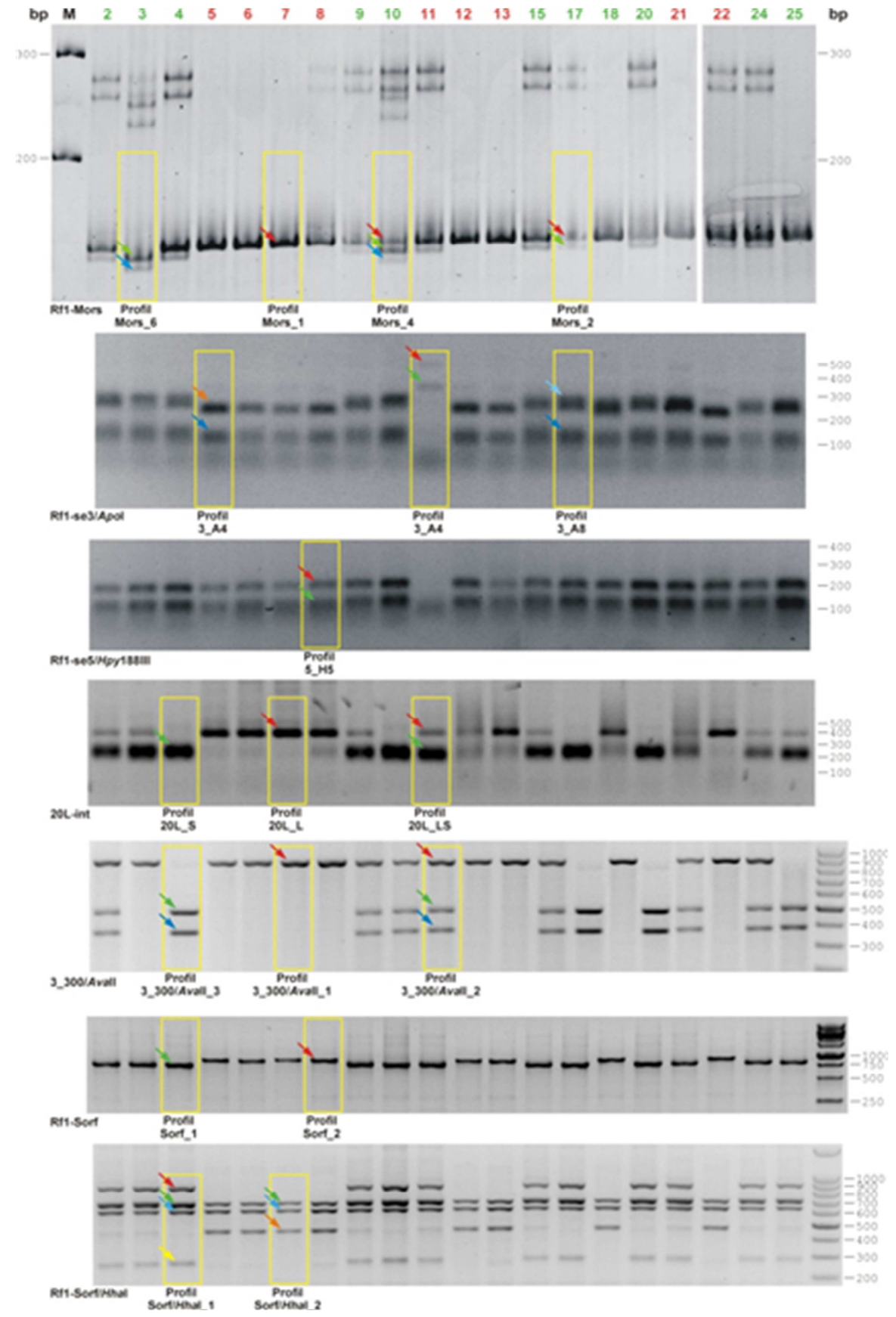

Rys. 1. Profile siedmiu markerów genu $X(R f 1)$ u wybranych roślin z populacji 398. Czerwona czcionka — rośliny męskosterylne, zielona czcionka — rośliny męskopłodne. $\mathrm{M}$ — wzorzec wielkości fragmentów DNA 
TEMAT BADAWCZY 5: ANALIZA NIERÓWNOWAGI SPRZĘŻEŃ - GENOTYPOWANIE ZESTAWU MĘSKOSTERYLNYCH OBIEKTÓW HODOWLANYCH PRZY ZASTOSOWANIU OPRACOWANYCH MARKERÓW PCR

\section{Cele tematu}

Określenie, czy genotypy loci restorerowych wykazują zależność od genotypów w wybranych loci markerowych

\section{Opis wyników}

Badany materiał roślinny stanowiła kolekcja 12 linii męskosterylnych, testowano po 10 roślin każdej z linii. Poddano je genotypowaniu czterema markerami dla genu $X(R f I)$ i dwoma markerami dla genu $Z(R f 2)$. Markery te reprezentowały typy CAPS i SCAR. W badanym zestawie linii męskosterylnych markery dla genu Z/Rf2 (ppr681/HpaII i ppr821/Fs $p$ BI) były monomorficzne. Spośród przetestowanych markerów dla genu X/Rf1 dwa (Rf1_Mors, Rf1-se3/ApoI) cechowała dominacja jednego profilu elektroforetycznego - w obrębie ośmiu (Rf1_Mors) / dziewięciu (Rf1-se3/ApoI) linii był on obserwowany u wszystkich badanych roślin. Pozostałe dwa markery dla genu X/RfI cechowała wyraźna segregacja między- i wewnątrz obiektowa obserwowanych profili elektroforetycznych.

\section{Wnioski}

- Dane wskazujące na istnienie nierównowagi sprzężeń pomiędzy allelami loci markerowych oraz allelem w locus restorera uzyskano dla obydwu markerów genu $Z$ $(R f 2)$ i dwóch (spośród czterech testowanych) markerów genu $X(R f 1)$. 
